\title{
Investment analysts paint rosy prospect for biotech
}

[SAN FRANCISCO] After a sluggish stock performance in the second half of 1996, the US biotechnology industry is poised for unprecedented growth in 1997, according to stock analysts who point to the large number of new drugs being developed, strong finances and an improved regulatory environment.

Persuaded by this optimistic assessment, investors at the annual Hambrecht \& Quist Health Care Conference in San Francisco last week were hastily buying shares in the companies that announced details of 200 drugs in late-stage clinical trials.

The data on those treatments are likely to be released during the next 18 months. Regeneron, Alpha-Beta, AutoImmune, Creative Biomolecules, BioChem Pharma and ImmunLogic are likely to be among the first to report on important trials.

Most companies are in a strong position to build on the results, according to Richard van den Broek, a biotechnology analyst at Hambrecht \& Quist ( $H \& Q)$. The sector as a whole has recently raised US $\$ 5$ billion, and the average company has three years' supply of cash in its coffers, he said.

Analysts argue that drug developers are enjoying an improved relationship with the US Food and Drug Administration (FDA), which has cut drug approval times dramatically over the past two years. They also say that with the FDA commissioner, David Kessler, stepping down, biotechnology companies expect the changes to lose some momentum, but not to go into reverse.

The upbeat assessment is also based on the fact that some industry experts are expecting proposals to loosen standards of efficacy to get drugs to the market sooner. At the same time, some of the potential threats that had been feared by drug developers over the past year have not materialized.

A year ago, for example, company executives were concerned about the potential impact of managed care on the acceptance of innovative treatments. Managed-care companies are now moderating their emphasis on cost and demonstrating a greater interest in quality, said Robert Faulker, a medical devices analyst at $\mathrm{H} \& \mathrm{Q}$. This has helped development of drugs and devices, particularly those that had cost-benefit analyses built into their clinical trials.

Although companies are building on a strong year, investors did not do so well in 1996. After a profitable first half, biotechnology investments in the second half of the year lagged behind the broader market. Despite this, Dennis Purcell, managing director for life sciences investment banking at $\mathrm{H} \& \mathrm{Q}$, predicted healthy growth in company valuations and stock market returns for 1997.

Purcell pointed out that, over the first two days of the conference, 85 per cent of the companies that made presentations enjoyed stock price increases, even though the market was flat. One company, Geron, almost doubled in price. "1997 may be the year of the investor," said Purcell, who depicted biotechnology as a promising investment target.

Rachel Leheny, a biotechnology analyst with $\mathrm{H} \& Q$, argued that the industry appears to be entering an era of efficiency, in terms of both science and business management.

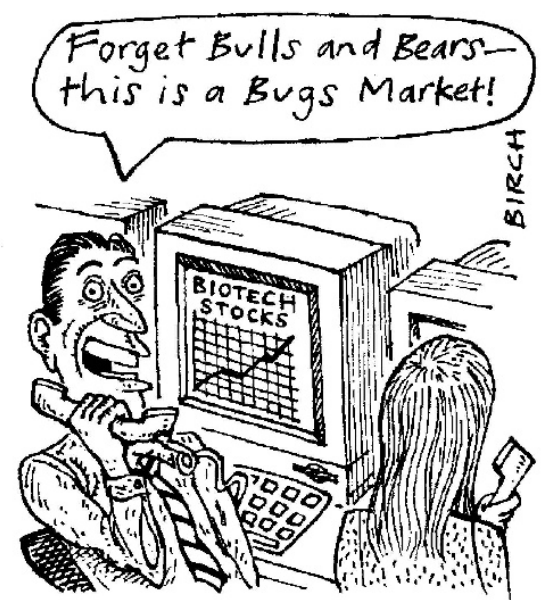

Important technology 'platforms', such as genomics, screening and combinatorial chemistry, are now in place, providing the means for rapid identification and development of well-targeted drugs. Not only are development times likely to improve, but the resulting drugs are likely to be more effective, she said. The result will be fewer clinical failures and a dramatic improvement over the pharmaceutical industry's current 10 per cent success rate in drug development.

According to Steven Burrill of the merchant bank Burrill \& Company, European companies are leading the way to programme swaps and other strategic links between companies. He said that Europe has become a hotbed of young companies as technology transfer out of the academic environment has accelerated. Purcell suggests that US companies may go to Europe to gain access to capital and to take advantage of patient and hospital systems there.

A flow of new discoveries has increased the attraction of the biotechnology industry to scientists, many of whom are moving to smaller companies from the major pharmaceutical corporations.

Sally Lehrman

\section{Glaxo Wellcome turns to worms for guidance on genes}

[SAN FRANCISCO] Just three months

after acquiring a subsidiary that specializes in nematode genetics, Sequana Therapeutics of La Jolla, California, has signed a research agreement with Glaxo Wellcome to use its technology for functional analysis of human disease genes.

According to Tim Harris, senior vice-president and chief technical officer at Sequana, the move reflects the fact that large pharmaceutical companies are beginning to recognize the value of less complex organisms for understanding the function of human genes, identifying targets for therapeutic approaches and getting them into screening.
Under the agreement, NemaPharm of Cambridge, Massachusetts, will use the nematode worm Caenorhabditis elegans as a model animal system to evaluate genes, characterize the pathways of their activity and identify targets for therapeutics.

The exact genes and their disease areas have not been disclosed.

Neither have the financial terms of the agreement been revealed, although Glaxo Wellcome says it will provide full research support and make payments when NemaPharm identifies targets that become part of Glaxo Wellcome's drug- discovery programmes.

NemaPharm is also to receive royalties on products that result.

The nematode is expected to be fully sequenced by 1998 . Of the 70 human disease genes cloned so far, more than half have known homologues in the worm. In a presentation at the Hambrecht \& Quist Health Care Conference in San Francisco last week (see above), Kevin Kinsella, chief executive of Sequana, emphasized the animal's wellunderstood biology and the ease with which its genes can be manipulated.

Among other things, NemaPharm has used the model to find a chemical that can block apoptosis, and to knock out a ras gene homologue and return its function to normal, Kinsella said. The company will do about one new gene knockout a week.

Sequana acquired NemaPharm in October. The company was set up in 1990 in Cambridge, Massachusetts, with founders that included Robert Horvitz, professor of biology at the Massachusetts Institute of Technology:

Along with computational biology, the work of the subsidiary has since become crucial to Sequana's functional genomics programme, said Harris. 